KEMAS 14 (1) (2018) 1-9
Jurnal Kesehatan Masyarakat

\title{
Climatology Influence on Malaria Cases in Alusi Community Health Center, West Southeast Maluku Regency
}

Semuel Sandy ${ }^{1 \bowtie}$, Ivon Ayomi ${ }^{1}$

${ }^{1}$ Papua Biomedical Research Institute, Indonesia

\begin{tabular}{l} 
Article Info \\
\hline Article History: \\
Submitted November 2015 \\
Accepted Juni 2018 \\
Published July 2018 \\
\hline Keywords: \\
Malaria, rainfall, humidity, \\
temperature, wind velocity \\
\hline DOI \\
https://doi.org/10.15294/ \\
kemas.v14i1.4553
\end{tabular}

\begin{abstract}
The west Southeast Maluku regency is a malaria endemic area with API of 29.99 / 1000 in 2014. Malaria is affected by climatology, therefore climatological changes can be used to predict increase in malaria cases. We used times series study research method of the climatology influence on malaria cases in Alusi Community Health Center. We used secondary data of malaria cases from Alusi Community Health Center and climatologic data (rainfall, wind speed, humidity temperature) from Saumlaki Meteorological, Climatology, and Geophysical Agency. The research was conducted in March-April 2016 in West Southeast Maluku Regency. The data was analysed by linear regression. The proportion of malaria cases was 38.3\%; most infection occured in patients over 15 years old (71 cases). The linear regression analysis of climatological influence on malaria cases were as follows: humidity was $\mathrm{r}=0.382$; $\mathrm{R} 2=0.146 ; \mathrm{p}=0.220, \mathrm{r}=0.172$ temperature was; $\mathrm{R} 2=0.03 ; \mathrm{p}=0.592, \mathrm{r}=0.345$, rainfall was; $\mathrm{R} 2=0.119 ; \mathrm{p}=0.272$, and wind velocity was $\mathrm{r}=0.07 ; \mathrm{R} 2=0.005 ; \mathrm{p}=0.828$. We could concluded that climatology parameters showed positive correlation, but statistically insignificant relationship with malaria cases $(\mathrm{p}<0.05)$.
\end{abstract}

\section{Introduction}

Malaria is a disease caused by the parasite Plasmodium spp. The disease is transmitted by Anopheles spp mosquitoes. Globally, malaria is widespread in the area between longitudes $60^{\circ}$ in the north and $40^{\circ}$ south, which include more than 100 tropical and subtropical countries. The population at risk for malaria is about 2.3 billion or $41 \%$ of the total world population (WHO, 2000).

Totally 3.3 billion people globally are estimated to be at risk for malaria or other disease. 1.2 billion people are at high risk for malaria infection (more than 1 in 1000, of the population infected with malaria annually). Around 198 million cases of malaria occurred globally in 2013 (uncertainty range of 124 - 283 million) and caused 584,000 deaths (uncertainty range of $367,000-755,000$ ). The heaviest burden was in Africa, where it was estimated that $90 \%$ of all deaths was caused by malaria infection, and $78 \%$ of all the dead was aged under 5 years old. 1.4 billion people from South Asia countries were estimated to be at risk for malaria infection. There were 10 endemic countries with 352 million people at a high risk for malaria infection. The proportion of malaria infection caused by P. falciparum and P. vivax varied in the region (WHO, 2014).

Malaria is one of the largest cause of death, especially in high-risk groups, which is infants, toddlers, and pregnant women. Malaria 
causes anemia and could lower productivity. In 2010 , there were $65 \%$ of malaria endemic regencies in Indonesia where about $45 \%$ of the population was at risk of contracting malaria. Community survey result during 2007-2010 showed that the prevalence of malaria in Indonesia has decreased from $1.39 \%$ to $0.6 \%$. In addition, based on reports received in 20002009, malaria morbidity rate has decreased from 3.62 per 1,000 population in 2000 to 1.85 per 1,000 population in 2009 to 1.96 per 1000 population in 2010 (Kementerian Kesehatan

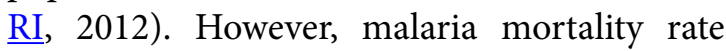
reached 1.3\%. Although national Annual Parasite Incidence (API) has decreased, areas with high malaria cases still had higher than national average API, whereas outbreak frequently occur in areas with low malaria cases because of imported cases. In 2011, there were 388 deaths due to malaria. The national prevalence of malaria was $0.6 \%$ according to Basic Health Research data in 2010; provinces with API above the national average were West Nusa Tenggara, Maluku, North Maluku, Central Kalimantan, Bangka Belitung, Riau, Bengkulu, Jambi, Central Sulawesi, Gorontalo and Aceh. The highest prevalence rates was found in eastern Indonesia, namely in West Papua (10.6\%), Papua (10.1\%), and East Nusa Tenggara (4.4\%) (Kementerian Kesehatan RI, 2012).

West Southeast Maluku Regency (Maluku Tenggara Barat / MTB) is an administrative region of Maluku provincial government. Geographically, West Southeast Maluku (MTB) is located at $6^{\circ}-8^{\circ} 30$ 'south latitude and $125^{\circ} 45^{\prime}$ - $133^{\circ}$ East Longitude. West Southeast Maluku Regency is an area where Tanimbar Islands is located and has a west and east monsoon seasons transitioned by transitional season. West season runs in October-March and has many rainy days. High rainfall occurs during December-March. Transition season occurs in March/April and October/November. The average temperature in MTB is $27.6^{\circ} \mathrm{C}$, with a minimum temperature of $22.4^{\circ} \mathrm{C}$ and maximum of $33.1^{\circ} \mathrm{C}$ (BPS Kabupaten Maluku Tenggara Barat, 2010).

Malaria transmission occurs because of the interaction between definitive host (Anopheles spp), intermediate host (human), and agents of disease (Plasmodium spp). The development of malaria depends on the climate change. Transmission of malaria depends on the fluctuations of the vector whereas the vector is influenced by climatological change (rainfall, ambient temperature, and humidity) (Haque et al., 2010). The existence of vector is also influenced by geography, bio-geographic, and geophysical factors. In addition to aforementioned factors, land usage, socioeconomic, and behavioral changes also support the spread of malaria (Rahardjo, 2011).

Indonesia is an archipelago with tropical climate and quickly affected by regional and global climate change. Macro and micro climate change can contribute significantly to the spread of infectious diseases, including mosquito-borne disease vectors (Suwito et al., 2010). Increased humidity and rainfall is directly proportional to the increase in mosquito density, whereas the optimum limit temperature for mosquito breeding is in $25^{\circ}$ to $27^{\circ} \mathrm{C}$ (Epstein et al., 1998).

The types of disease experienced by people in West Southeast Maluku Regency varies. The leading diseases were acute respiratory infections (ARI), skin diseases, rheumatism, and malaria (BPS Kabupaten Maluku Tenggara Barat, 2010). From interviews, it was mentioned that malaria is a prominent disease throughout West Southeast Maluku, in addition to tuberculosis (TB) for some areas. Annual Parasite Incidence (API) data of Alusi-Kelaan Community Health Center showed that malaria cases in 2010 was 18 per 1000 population, whereas API in 2011 was 12.02 per 1000 population, API in 2012 was 27.01 per 1000 population, API in 2013 was 53.5 per 1000 population, and API in 2014 was 29.99 per 1000 population. The API data illustrates that the West Southeast Maluku Regency was still highly endemic (API> 5 per 1000 population). Malaria still remains a health problem in West Southeast Maluku Regency. Therefore, basic data on malaria epidemiology is needed, especially climatological influence on the increase of malaria cases through indirect effect on the survival of malaria vectors. This article aimed to analyze the climatological influence on malaria cases in West Southeast Maluku Regency, particularly in the Alusi- 
Kelaan Community Health Center.

Method

The study design was climatological study with times series studies of malaria cases and climatological data from January to December 2014 using analytical observation. Times series study (time trend study) is a study to examine the relationship of disease frequency in the community associated with climatological factors. The study was conducted in March-April 2015 in West Southeast Maluku District (Research Permit Recommendation from National Unity and Political Office of Maluku Province No. 074/50/BKBP/II/2015). The study aimed to review the climatological influence on malaria cases at Alusi-Kelaan Community health center. We used secondary data of climatological factor which were average monthly rainfall, average monthly wind velocity, average monthly temperatures and average monthly humidity. These data was obtained in Meteorological, Climatology, and
Geophysical Agency station in Saumlaki City of West Southeast Maluku Regency. Monthly malaria case data in 2014 was obtained from West Southeast Maluku Public Health Office and Alusi-Kelaan Community Health Center in Komormolin District, West Southeast Maluku Regency in 2014. We analyzed the data with Klomogorov-Smirnov (KS) to see whether the data variables were distributed normally or not. If the data was normally distributed, we would use linear regression parametric statistical tests while if not, we would use Spearman nonparametric statistical test.

\section{Results and Discussion}

Figure 1 shows that malaria cases were found in the village of Kelaan and Kilmasa. Malaria cases were always present every month and peaked in January-March where there was a change from west monsoon climate to the east monsoon climate. Figure 2 shows the distribution of malaria cases by age group and gender. The number of malaria case was larger

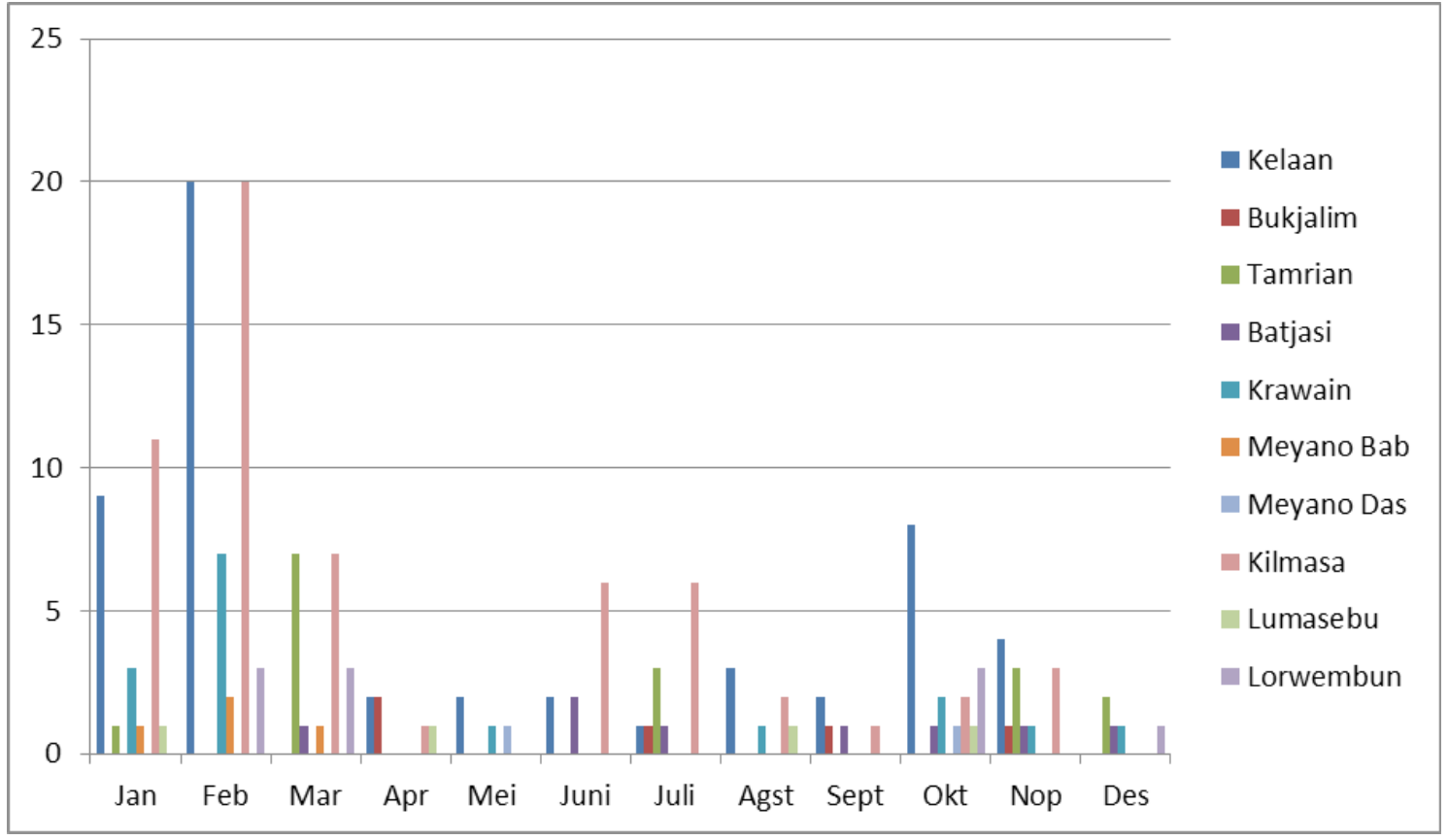

Figure 1. Distribution of malaria cases in Alusi-Kelaan Community Health Center in 2014 Source: Puskesmas Alusi, 2014 


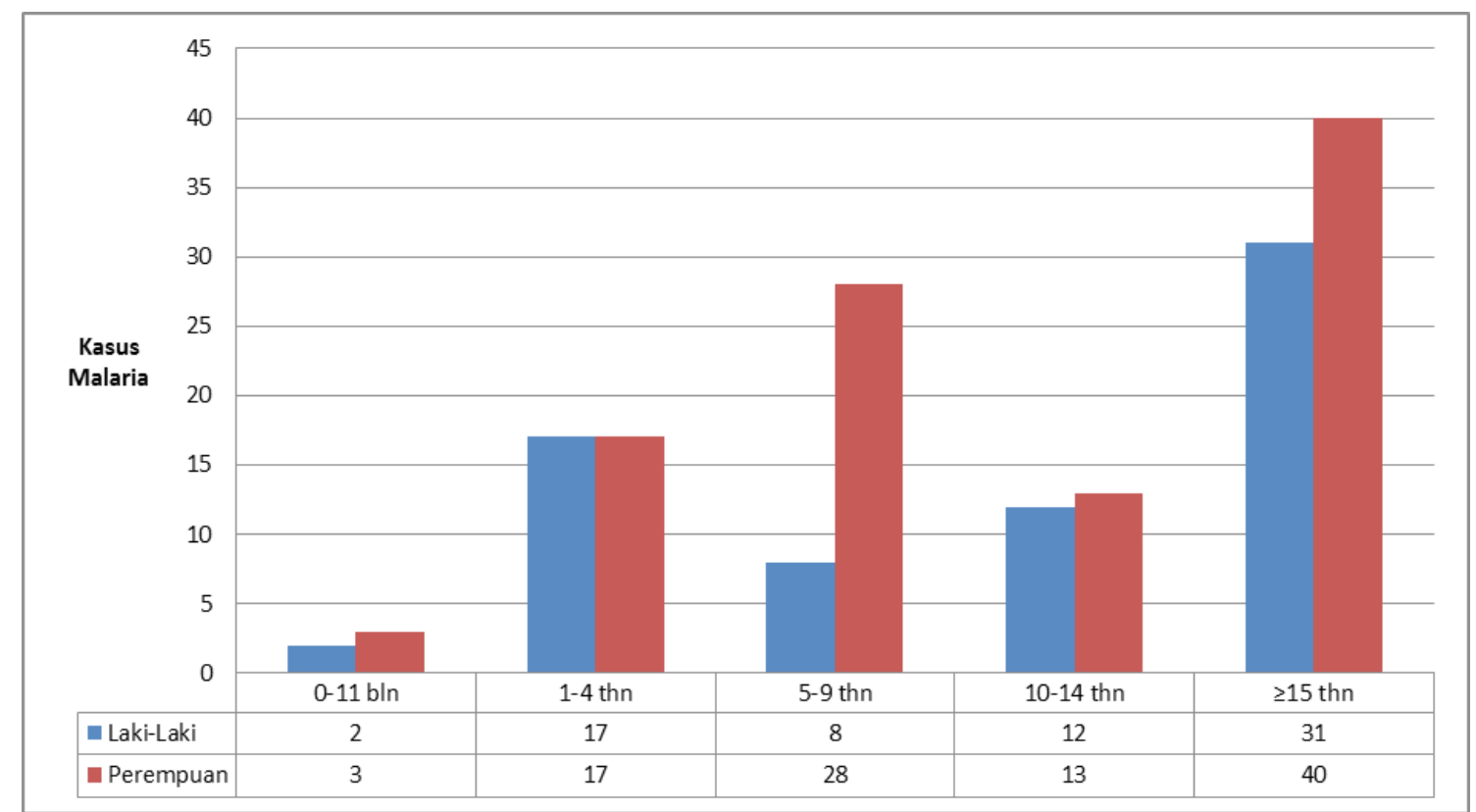

Figure 2. Malaria Cases Distibuted by Age Group in Alusi-Kelaan Community Health Center 2014 Source: Puskesmas Alusi, 2014

Table 1. Results of Monthly Microscopic Malaria Examination and RDT Examination at AlusiKelaan Community Health Center in 2014

\begin{tabular}{lllllll}
\hline Month & $\begin{array}{l}\text { Clinical } \\
\text { Malaria }\end{array}$ & $\begin{array}{l}\text { Examination } \\
\text { Microscopic }\end{array}$ & RDT & P.falciparum & P. vivax & Malaria case \\
\hline January & 43 & 30 & 13 & 22 & 2 & 24 \\
February & 83 & 83 & 0 & 20 & 30 & 50 \\
March & 30 & 26 & 4 & 8 & 10 & 18 \\
April & 34 & 21 & 13 & 3 & 3 & 6 \\
May & 15 & 11 & 4 & 0 & 4 & 4 \\
June & 30 & 28 & 2 & 1 & 9 & 10 \\
July & 40 & 40 & 0 & 1 & 11 & 12 \\
August & 32 & 32 & 0 & 1 & 6 & 7 \\
September & 30 & 30 & 0 & 1 & 4 & 5 \\
October & 35 & 32 & 3 & 9 & 8 & 17 \\
November & 35 & 35 & 0 & 1 & 12 & 13 \\
December & 40 & 40 & 0 & 0 & 5 & 5 \\
\hline Total & 447 & $408(91.7 \%)$ & $39(87.6 \%)$ & $67(14.9 \%)$ & $104(23.3 \%)$ & $171(38.3 \%)$ \\
\hline SOurce Pus & & & &
\end{tabular}

Source: Puskesmas Alusi, 2014

in people aged $>15$ years $(71$ cases) and more dominant in female (40 cases) compared to men (31 cases).

Table 1 shows that in a year, there were 171 positive cases of malaria $(38,3 \%)$ in Alusi-Kelaan Community Health Center out of 447 patients with clinical sign of malaria. 104 malaria cases (23.3\%) was caused by Plasmodium vivax and 67 cases $(87.6 \%)$ was caused by Plasmodium falciparum.
Figure 3 shows the average temperature in Saumlaki where the highest temperature occured in November $\left(28.6^{\circ} \mathrm{C}\right)$ and the highest average temperature occurred in January-June $\left(26.6-27.5^{\circ} \mathrm{C}\right)$. An increase of malaria cases also occurred in January-March following the pattern of temperature rise.

Figure 4 showed the mean monthly rainfall data in 2014 where the highest rainfall occured in January to June which ranged from 


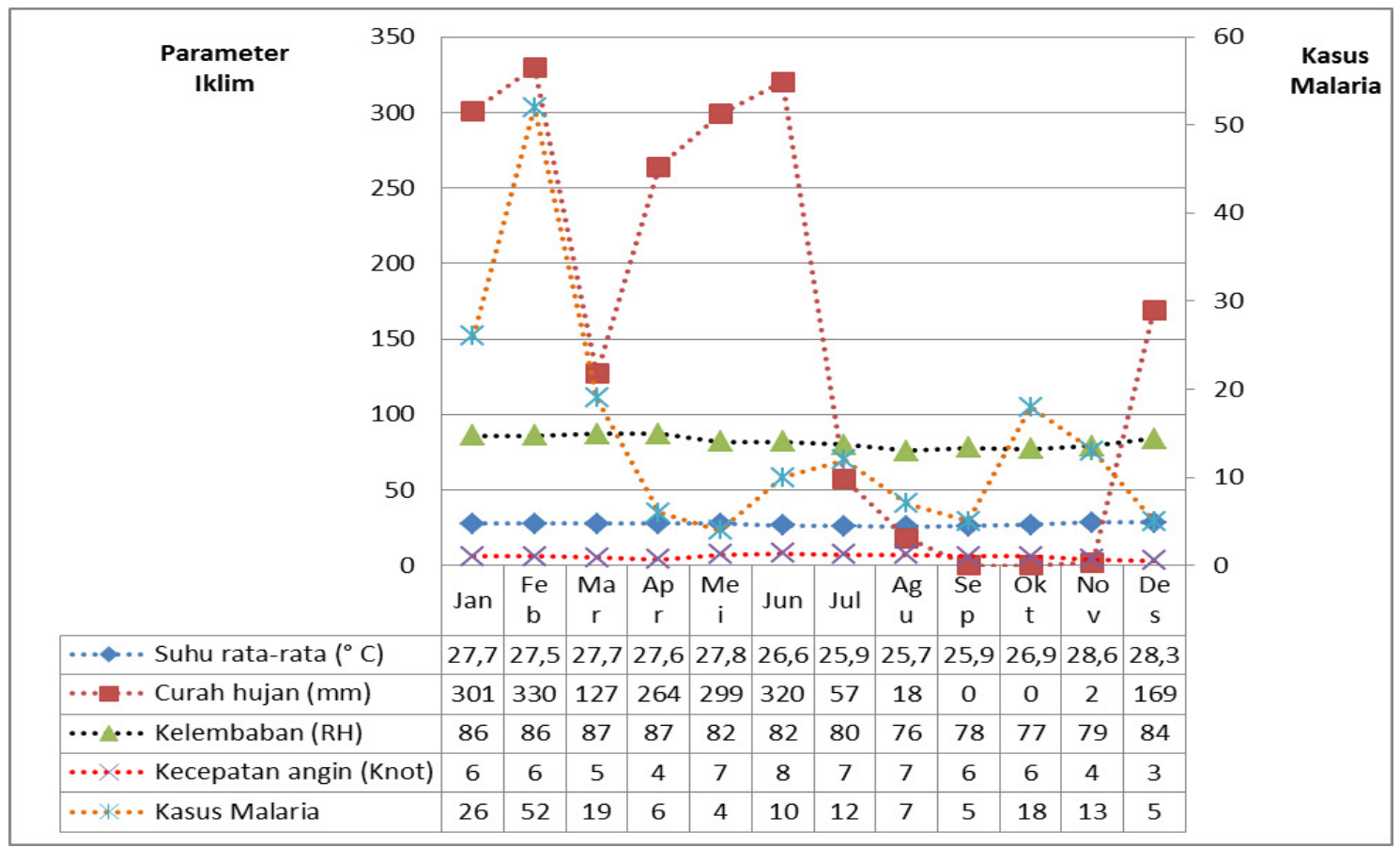

Figure 3. Malaria Cases Based on Temperature, Monthly Rainfall, Humidity, Wind Velocity Source: Puskesmas Alusi, 2014

127 to $330 \mathrm{~mm}$ rainfall volume. Associated with high rainfall, malaria cases also increased in January to March, ranged from 19-53 cases.

The highest number of malaria cases was in January-March, in which the monthly air humidity was also high at $86-87 \%$.

Monthly average wind velocity in 2014 where the highest wind velocity was in June at 8 knots and the lowest was in November and December (4 and 3 knots). High malaria cases also occurred in the month where wind velocity was high, which was January-February and June-August.

Table 2 showed that data normality test for climatological data and malaria cases using Kolmogorov-Smirnov test obtained $\mathrm{p}$ value $>0.05$, therefore the variables tested had normal data distribution and hence was further analyzed with linear regression test. Table 3 showed the results of multiple linear regression analysis of climatological variables which were rainfall, humidity, temperature, and wind velocity.

The illustration of malaria cases in West Southeast Maluku Regency could be seen from annual parasite incidence (API) in 2010 until 2013 where it increased and then decrease in 2014. From monthly malaria case in 2014, the highest number of cases occurred in JanuaryMay and in December. The groups at higher risk for malaria were women and people aged $>15$ years old. The number of clinical malaria patients were 447 people $91.7 \%$ of whom were confirmed microscopically diagnosed are $91.7 \%$ and $87.6 \%$ by rapid diagnostic test (RDT). 171 patients were positive for malaria, resulting in a proportion of malaria case $38.8 \%$ in 2014 . The main malaria species that infected population in the working region of Alusi-Kelaan Community Health Center were Plasmodium vivax (23.3\%) and Plasmodium falciparum (14.9\%). Malaria incidence in a region is influenced by several factors. Factors that directly affect malaria cases is usually called vectorial capacity, which is the average number of people bitten and infected by malaria sporozoite by an anopheles mosquito in a unit of time. Indirect factors are climatological situation such as temperature, humidity, rainfall, wind velocity that affect biting activity, age, and flight distance of mosquitoes (Duarsa, 2008).

West Southeast Maluku Regency consist of Tanimbar Islands and is located in Maluku Province. This regency have west and east monsoon seasons transitioned by transitional season. West monsoon season occurs in 
Table 2. Liner Regretion Analysis of Climatology and Monthly Malaria Case at Alusi Community Health Centre Year 2014

\begin{tabular}{|c|c|c|c|c|c|c|c|}
\hline \multirow[t]{2}{*}{ Variabel } & \multicolumn{3}{|c|}{$\begin{array}{c}\text { Normality Test } \\
\text { Kolmogorof Smirnov }\end{array}$} & \multirow[t]{2}{*}{$\mathbf{r}$} & \multirow[t]{2}{*}{$\mathbf{R}^{2}$} & \multirow[t]{2}{*}{ Linear Equation } & \multirow[t]{2}{*}{$p$ value } \\
\hline & Statistic & df & $p$ value & & & & \\
\hline $\begin{array}{l}\text { Monthly } \\
\text { Rainfall }\end{array}$ & 0.195 & 12 & 0.200 & 0.345 & 0.119 & $\begin{array}{l}\text { Malaria Case }=0.032^{\star}[\text { Monthly } \\
\text { Rainfall }]+9.233\end{array}$ & 0.272 \\
\hline Humidity & 0.175 & 12 & 0.200 & 0.382 & 0.146 & $\begin{array}{l}\text { Malaria Case }=1.227^{*}[\text { Humidity }]- \\
86.386\end{array}$ & 0.220 \\
\hline Temperature & 0.211 & 12 & 0.145 & 0.172 & 0.030 & $\begin{array}{l}\text { Malaria Case }=2.284^{*} \\
{[\text { Temperature }]-47.825}\end{array}$ & 0.592 \\
\hline $\begin{array}{l}\text { Wind } \\
\text { Velocity }\end{array}$ & 0.234 & 12 & 0.070 & 0.070 & 0.005 & $\begin{array}{l}\text { Malaria Case }=0.608^{\star}[\text { Wind } \\
\text { Velocity }]+10.753\end{array}$ & 0.828 \\
\hline
\end{tabular}

October - March and has more rainy days. Highest rainfall occurs in December - March. Transitional season occurs in March/April and October/November. Mean temperature at West Southeast Maluku is $27.6^{\circ} \mathrm{C}$, with minimum temperature of $22.4^{\circ} \mathrm{C}$ and maximum of 33.1 ${ }^{\circ} \mathrm{C}$ (Kementerian Kesehatan, 2012).

According to climatology data, high rainfall occurs in January - June. January - March is west monsoon season, in April transitional season has started with low rainfall. Highest wind velocity occurs in May - October.

The influence of air temperature fluctuation toward malaria case can be seen in Figure 3. Highest air temperature occurs in November $\left(28.6^{\circ} \mathrm{C}\right)$ in which there is relatively moderate number of malaria case. The number of malaria case was high in January - March when the mean temperature was $27^{\circ} \mathrm{C}$. Temperature influences sporogonic or extrinsic cycle of mosquito. Higher temperature shorten the cycle while lower temperature extend the cycle. The conducive temperature for mosquito's growth is $25-30^{\circ} \mathrm{C}$; growth will stop if the temperature is $<10^{\circ} \mathrm{C}$ and $>40^{\circ} \mathrm{C}$. The optimum temperature for mosquito's growth is $25-27^{\circ} \mathrm{C}$ (Mofu, 2013). Mean air temperature in West Southeast Maluku Regency $\left(27^{\circ} \mathrm{C}\right)$ was the optimum temperature for growth of Anopheles $s p p$. Linear regression result showed correlation coefficient $\mathrm{r}=0.172$ with determination coefficient $\left(\mathrm{r}^{2}\right)$ is 0.030 , thus it was concluded that there was positive correlation between increase in temperature and the number of malaria case, but the contribution of temperature influence was $3 \%$. Temperature is one of the environment factor affecting mosquito's growth and extrinsic cycle. Warmer temperature hastens the growth but decreases lifespan of adult mosquito. This temperature also increase frequency of blood sucking to continue their life cycle (Rahardjo, 2011). Our study did not find significant relationship between temperature and number of malaria cases in Alusi-Kelaan Community Health Center $(\mathrm{p}=0.592)$. Similar study by Tesfaye et al., (2012) and Chafidhah et al., (2010) showed that there was no significant association between temperature and number of malaria cases. This showed that the increase in malaria cases was only marginally influenced by temperature as seen from determination coefficient $3 \%$ while the remaining $97 \%$ was influenced by other factors (Tesfaye et al., 2012). Mofu et al., (2013) stated that there was no significant relationship between temperature and increase in malaria case; in fact there was negative correlation with the number of case.

Air humidity affects mosquito's growth cycle and blood sucking habit. Lower humidity shorten mosquito's lifespan and higher humidity extend the lifespan. Higher humidity cause mosquito to be more active and suck blood more often (Suwito et al., 2010). Humidity and rainfall increase the density of Anopheles spp. (Epstain et al., 1998). The high population of Anopheles spp. increase the population of malaria vector so it increases malaria incidence in certain areas (Mardiana \& Munif, 2009). There was positive correlation $(r=0.382)$ between air humidity and number of malaria case in Alusi-Kelaan Community Health Center, meaning that increased air humidity increase the number of malaria cases. The determination coefficient $\left(\mathrm{R}^{2}=0.146\right)$ showed 
air humidity influenced $14.6 \%$ for malaria case's increase and while the remainder was affected by other factors. Our analysis also showed there no significant correlation between the number of malaria cases and air humidity $(\mathrm{p}=0.220)$. These results are supported by several studies, one of them is Guarda et al., (1999) which stated that there was no significant correlation between air humidity of $83-97 \%$ and number of malaria cases in Amazon. Other studies stated that there was significant correlation between them, such as study in several Iranian cities by $\underline{\text { Fataei \& Madadi (2011). Similar study by Xiao }}$ et al., (2010) and Tian et al., (2008) in China with temporal analysis between relative air humidity and malaria case showed insignificant relationship. This was different with Chafidhah et al., (2010) who analyzed the influence of high humidity on malaria case and found that humidity affected malaria incidence 4.79 times higher compared to low humidity. Humidity is influenced by temperature, rainfall, sunlight, and water flow, hence humidity in West Southeast Maluku was fluctuative. The presence of coconut farm and dense forest resulted in lower ground temperature and higher humidity which support the growth of Anopheles $s p p$., especially as resting place after sucking human's/animal's blood (Mardiana \& Febrianto, 2009; Chafidhah, 2010). Such condition helps Anopheles spp. to mature their eggs and survive in the nature (Dt Manguan, 2015).

High rainfall increases the number of larvae, resulting in increased Anopheles spp. population. In addition, rainfall also increase air humidity so it lengthen mosquito's lifespan (Alemu et al., 2011). Linear regression analysis showed positive correlation between rainfall and increase in malaria cases $(\mathrm{r}=0.345)$ with determination coefficient $\mathrm{R}^{2}=0,119(\mathrm{p}=0,272)$. We could conclude that increased rainfall affected malaria case, however the degree of influence was only $11.9 \%$ while the remainder was influenced by other factors. Medium rainfall forms larvae's habitat, but also destroys mosquito's habitat if the rainfall is too high and causes flood which washes away the eggs and larva (Alemu, et al., 2011; Duarsa, 2008). This result is supported by Rahmawati et al., (2012) which showed that rainfall has no significant influence towards number of malaria cases because high rainfall reduces Anopheles spp. activity.

Wind velocity is an indirect factor that influence the increase in malaria case. Figure 5 shows the wind velocity was approximately 5 knots every month. Villages around AlusiKelaan Community Health Center are close to the beaches and have two climates, which are west and east monsoon. At night, wind velocity usually increases. The analysis result showed positive correlation between wind velocity and increase in malaria cases $(r=0.007)$ with determination correlation $R^{2}=0,005$. From the determination correlation, we could see that wind velocity only contributed $5 \%$ of the increase in malaria cases. Wind velocity affects mosquito's flight distance in order to contact human. Wind veocity of $11-14 \mathrm{~m} / \mathrm{s}$ can prevent mosquito's flight (Duarsa, 2008).

Overall, climatological factors were positively correlated with the number of malaria cases, however the correlation was not statistically significant because other factors such as social-economy and community mobility causing imported malaria case also affect the number of malaria cases. Global climate effect varies in different locations, depending on geographic position of the country or area (Nwagbara, 2015). Climatology effect on malaria cases also varies in different areas as reported by Fataei \& Madadi, (2011). Presence of malaria's vector also influenced by environment factor that affected their ability to live and growth. The variation and degree of environment's influence is large, not only through abiotic factors such as rain and temperature which affect mosquito density and parasite growth inside the vector, but also biotic factors such as deforestation, agriculture, house construction, human population and urbanization (Mohan \& Naumova, 2014; Caminade et al., 2014). The impact of deforestation on temperature, rain, and humidity interacts with each other in affecting macro and micro climate in mosquito's habitat (Duarsa, 2008).

\section{Conclusion}

The analysis of secondary data in AlusiKelaan Community Health Center found a positive correlation between climatological factors and number of malaria cases, however 
the correlation was not statistically significant. The effect of climatological factors toward number of malaria case was relatively low as shown by the low determination coefficient. Climate is an indirect factor that can influence the number of malaria cases.

\section{Acknowledgments}

We would like to thank the Head of West Southeast Maluku Health Office, Head of West Southeast Maluku Disease Prevention and Control, Head of Alusi-Kelaan Community Health Center and Malaria Controller from Alusi-Kelaan Community Health Center who helped us in collecting secondary data on malaria. We also thank the Head of West Southeast Maluku Meteorogical, Climatology, and Geophysical Agency Station who helped us by giving climatological data and the Head of Papua Biomedical Research and Development who facilitated the writing of this study.

\section{References}

Alemu, A., Abebe, G., Tsegaye, W., Golassa, L., 2011. Climatic Variables and Malaria Transmission Dynamics in Jimma Town, South West Ethiopia. Parasites and Vectors, 4, pp.30.

BPS Kabupaten Maluku Tenggara Barat, 2010. Maluku Tenggara Barat Dalam Angka 2010. Badan Pusat Statistik Kabupaten Maluku Tenggara Barat.

Caminade, C., Kovats, S., Rocklov, J., Tompkins, A.M., Morse, A.P., Colón-González, F.J., Stenlund, H., Martens, P., \& Lloyd, S.J., 2014. Impact of Climate Change on Global Malaria Distribution. PNAS, 111(9), pp.3286-3291.

Chafidhah I.U., \& Handayani O.W.K., 2010. Hubungan Sanitasi Lingkungan Perkebunan Salak Dengan Kejadian Penyakit Malaria. Jurnal Kesehatam Masyarakat, 5(2), pp.112118.

Duarsa, A.B.S., 2008. Dampak Pemanasan Global Terhadap Risiko Terjadinya Malaria. Jurnal Kesehatan Masyarakat, 2(2), pp.181-85.

Dt Manguang, M., 2015. Risks Factors of Malaria Incidence With Spasials Approaching. Jurnal Kesehatan Masyarakat,10(2), pp.129-136.

Epstein, P.R., Diaz, H.R., Elias, S., Grabherr, G., Graham, N.E., Martens, W.J.M., Thomson, E.M., \& Susskind, J. (ED)., 1998. Biological and Physical Signs of Climate Change: Focused on Mosquito Borne Diseases. Bul Amer Meterol Soc, 79, pp.409-17.

Fataei, E., \& Madadi, M., 2011. Survey Relation of Malaria Disease to Environmental Factors: A Case Study. World Journal of Zoology, 6(3), pp.323-327.

Guarda, J.A., Asayag, C.R., \& Witzig, R., 1999. Malaria Reemergence in the Peruvian Amazon Region. Emerging Infectious Diseases, 5(2), pp.209-2015.

Haque, U., Hashizume, M., Glass, G.E., Dewan, A.M., Overgaard, H.J., \& Yamamoto, T., 2010. The Role of Climate Variability in the Spread of Malaria in Bangladeshi Highlands. PLoS ONE, pp 5.

Kementerian Kesehatan. 2012. Penatalaksanaan Kasus Malaria di Indonesia. Kementerian Kesehatan.

Mardiana., \& Febrianto, D., 2009. Hubungan Karakteristik Lingkungan Luar Rumah dengan Kejadian Penyakit Malaria. Jurnal Kesehatan Masyarakat, 5(1), pp.11-16.

Mardiana, M.A., 2009. Hubungan antara Kepadatan Vektor Anopheles aconitus dan Insiden Malaria di Daerah Endemik di Kabupaten Sukabumi Jawa Barat. Jur Ekol Kes, 8(1), pp.901-914.

Mofu, R.M., 2013. Hubungan Lingkungan Fisik, Kimia dan Biologi dengan Kepadatan Vektor Anopheles di Wilayah Kerja Puskesmas Hamadi Kota Jayapura. Jurnal Kesehatan Lingkungan Indonesia, 12(2), pp.120-126.

Mohan, V,R., \& Naumova, E.N., 2014. Temporal Changes in Land Cover Types and the Incidence of Malaria in Mangalore, India. International Journal of Biomedical Research, 5(8), pp.494-498.

Nwagbara, M.O., \& Aruocha, C., 2015. Effects of Climate Change on Malaria Occurrence and Food Security in the Humid Tropics: An Example from Umuahia-South. Southeastern Nigeria, International Journal of Environmental Science and Toxicology Research, 3(3), pp. 43-48.

Rahmawati, S.L., \& Raharjo, N.M., 2012. Evaluasi Manajemen Lingkungan Pengendalian Vektor Dalam Upaya Pemberantasan Penyakit Malaria di Kota Ternate. Jurnal Kesehatan Lingkungan Indonesia, 11(2), pp.172-181.

Rahardjo, M., 2011. Malaria Vulnerability Index (Mvi) Untuk Manajemen Risiko Dampak Perubahan Iklim Global Terhadap Ledakan Malaria di Indonesia. Jurnal Vektor dan Reservoir Penyakit, 3(1), pp.54-80.

Suwito, U.K.H., Sigit, S.H., \& Sukowati, S., 2010. Hubungan Iklim, Kepadatan Nyamuk Anopheles dan Kejadian Penyakit Malaria, Jurnal Entomol Indon, 7(1), pp.42-53.

Tesfaye, S., Belyhun, Y., Teklu, T., Medhin, G., Mengesha, T., Petros, B., 2012. Malaria 
Pattern Observed in the Highland Fringe of Butajira, Southern Ethiopia: A Ten-Year Retrospective Analysis from Parasitological and Metrological Data. Malaria World Journal, 3(5), pp.1-8.

Tian, L., Bi, Y., Ho, S.C., Liu, W., Liang, S., Goggins, W.B., Chan, E.Y.Y., Zhou, S., \& Sung, J.J.Y., 2008. One-year Delayed Effect of Fog on Malaria Transmission: A Time-series Analysis in the Rain Forest Area of Mengla County, South-west China. Malaria Journal, 7, pp.110.
WHO, 2000. World Health Organization Expert Committe on Malaria. WHO Geneva.

WHO, 2014. World Malaria Report 2014: WHO Global Malaria Programme, World Health Organization. WHO Geneva.

Xiao, D., Long, Y., Wang, S., Fang, L., Xu, D., Wang, G., Li, L., Cao, W., \& Yan, Y., 2010. Spatiotemporal Distribution of Malaria and The Association between Its Epidemic and Climate Factors in Hainan, China. Malaria Journal, 9, pp.185. 